\title{
МЕДИЧНА РЕАБІЛІТАЦІЯ
}

\author{
DOI: 10.26693/JMBS03.01.211 \\ УДК 616-006-036.66-053.4-071:4-071:616-036.82:615.838
}

Шаповалова Г. А., Бабова І. К., Бабов К. Д.

\section{ХАРАКТЕРИСТИКА СТАНУ ІМУНІТЕТУ ДІТЕЙ У РЕМІСІЇ ОНКОЛОГІЧНИХ ЗАХВОРЮВАНЬ ПІСЛЯ БАЗИСНОГО АНТИКАНЦЦЕРОГЕННОГО ЛІКУВАННЯ}

\author{
ДУ «Український науково-дослідний інститут медичної реабілітації \\ та курортології МОЗ України», Одеса, Україна
}

gigienakurort@gmail.com

У результаті оцінки стану імунітету дітей у ремісії онкологічних захворювань після базисного антиканцерогенного лікування встановлено наступне.

Діти у ремісії ОГЗ, які надходили на СКЛ, мали порушення за даними розрахункових інтегративних показників імунологічної реактивності. Частіше це виявлялося після отримання комбінованої ХТ + ПТ. Порушення співвідношення активності клітинної та гуморальної ланок з пригніченням клітинної ланки імунітету (зниження ЛІ) виявлялись приблизно 3 однаковою частотою після різних протоколів базисного лікування. Порушення імунологічної реактивності у дітей, які надходили на СКЛ після радикального лікування 3Н, частіше проявлялись порушеннями активності клітин неспецифрічного та специфічного імунного захисту з пригніченням специфічного компоненту і не залежали від видів радикального лікування. Таким чином, у дітей, пролікованих з приводу $3 \mathrm{H}$, при надходженні на СКЛ з більшою частотою виявляються порушення всіх ланок імунітету, ніж у дітей у ремісії ОГЗ.

Ключові слова: діти, онкологічні захворювання, антиканцерогенне лікування, стан імунітету.

Зв'язок роботи 3 науковими програмами, планами, темами. Робота $є$ фрагментом наукової теми «Розробити диференційовані комплекси санаторно-курортної реабілітації найбільш поширених супутніх захворювань у дітей після радикального лікування онкопатології», № держ. реєстрації $0111 \mathrm{U} 004328$.

Вступ. Необхідність розвитку системи реабілітації дітей з онкологічними захворюваннями (О3) обумовлена високою частотою злоякісних новоутворень (3Н) як в Україні, так і багатьох країнах світу. За останні 10 років рівень дитячої інвалідності в Україні зріс на 1/3, в т.ч. в 2 рази у зв'язку із 3Н лімфатичної та кровотворної тканини. У структурі загальної захворюваності дітей відзначається збільшення О3 на 20\%. Причому, лише за останні 5 років на $26 \%$ зросла поширеність 3 Н серед підлітків $[1,2,5]$.

Мета дослідження: оцінка стану імунітету дітей у ремісії онкологічних захворювань після базисного антиканцерогенного лікування.

Об'єкт і методи дослідження. Оцінено стан імунітету у 152 дітей у ремісії онкогематологічних захворювань (ОГЗ) та ЗН після базисного лікування (оперативне лікування, ОЛ; хіміотерапія, ХT; променева терапія, ПТ) при надходженні на СКЛ. Діти були переважно у віці 4-12 років. 66 дітей у стані ремісії ОГЗ, переважно у ремісії гострого лімфобластного лейкозу (60,6\%) дітей, 86 дітей після радикального лікування 3Н центральної та периферичної нервової системи (36,1\%), нефробластом (16,3\%), ретинобластом (16,3\%). У дітей в ремісії ОГЗ переважали супутні захворювання нервової системи $(24,4 \%)$, органів дихання $(21,2 \%)$, органів гепатобіліарної системи (19,7\%).

Алгоритм обстеження дітей, які надходили на санаторно-курортне лікування (СКЛ), включав загальне клінічне обстеження (анамнез хвороби, наявність супутньої патології, скарги, клінічний огляд, вимірювання АТ, ЧД, ЧСС) та лабораторні дослідження (загальний аналіз крові). В оцінці імунологічної реактивності організму визначали інтегральні 
гематологічні показники: ЛІ (лімфоцитарний індекс); ІЛШОЕ - індекс співвідношення лейкоцитів і ШОЕ; ICHЛ - індекс співвідношення нейтрофілів та лімфоцитів; ICHM - індекс співвідношення нейтрофрілів та моноцитів; ІСЛМ - індекс співвідношення лімфоцитів та моноцитів; IA - індекс алергізації; ЛІІ - лейкоцитарний індекс інтоксикації [3, 4].

Усі досліди проводили у відповідності до Конвенції Ради Європи «Про захист прав людини і людської гідності в зв'язку з застосуванням досягнень біології та медицини: Конвенція про права людини та біомедицину (ЕTS № 164)» від 04.04.1997 р., і Гельсінської декларації Всесвітньої медичної асоціації (2008р.). Батьки кожного пацієнта підписували інформовану згоду на участь у дослідженні.

Результати дослідження та їх обговорення. У дітей в ремісії ОГЗ після отримання комбінованих курсів лікування при надходженні на СКЛ виявляли порушення співвідношень аферентної та ефрерентної ланок імунітету. Частіше серед цих відхилень виявляли пригнічення продукції ефекторних імунокомпетентних клітин - моноцитів (за підвищенням показників ІСЛМ). У дітей після базисного лікування з призначенням ХT цей показник був підвищений у 19,6\% дітей, після комбінованої терапії XТ + ПТ у 35,1\% обстежених.

Також визначені хронічні помірні зрушення макрофрагально-мікрофрагальної системи за підвищенням ICHM. У 54\% дітей показник ICHM підвищений до $(17,3 \pm 2,6)$ ум. од. після базисного лікування з застосуванням ХТ + ПТ. У дітей в ремісії ОГЗ після отримання курсів лікування з призначенням тільки XT при надходженні на СКЛ подібні зрушення були визначені з меншими відхиленнями до $(13,5 \pm 2,2)$ ум. од та з меншою частотою $35,3 \%$.

Порушення співвідношення активності клітинної та гуморальної ланок з пригніченням клітинної ланки імунітету (зниження за рівнем лімфоцитів індексу Гаркаві, ЛІ) виявляли у 25,5\% дітей після отримання ХT та у 16,2\% дітей після отримання комбінованої XТ + ПТ терапії, з підвищенням індексу співвідношення нейтрофрілів та лімфоцитів (ICHЛ) у цих групах дітей, що свідчить про зниження клітин специфічного захисту організму. Встановлено підвищення індексів алергізації (IA) у дітей після ХT та комбінованої XТ + ПТ терапії, більш виражене у першому випадку. Однак, при ХT частіше (у 25,5\% пацієнтів) при надходженні на СКЛ був знижений лейкоцитарний індекс інтоксикації (ЛІІ), що говорить про вірусне навантаження організму.

Отже, діти у ремісії ОГЗ, які надходили на СКЛ, мали порушення за даними розрахункових інтегративних показників імунологічної реактивності. Частіше це виявлялося після отримання комбінованої
XT + ПТ. Порушення співвідношення активності клітинної та гуморальної ланок з пригніченням клітинної ланки імунітету (зниження ЛІ) виявлялись приблизно з однаковою частотою після різних протоколів базисного лікування.

У $1 / 3$ дітей при надходженні на СКЛ після лікування ЗН встановлено пригнічення продукції ефекторних імунокомпетентних клітин моноцитів за даними підвищення індексу (ICЛМ), більші відхилення цього показника в середньому у $38 \%$ обстежених визначали після застосування протоколів ОЛ + XТ, $\mathrm{O}+\mathrm{XT}+$ П, найменьші відхилення та рідші у $21,6 \%$ обстежених після ОЛ.

Хронічні помірні зрушення макрофагальномікрофрагальної системи визначали з середньою частотою (45,6\%) після всіх видів радикального лікування, але більш підвищені показники ICHM визначали у випадках після отримання комбінованого радикального лікування О + ХT + П та О + ХT.

Порушення співвідношення активності клітинної та гуморальної ланок з пригніченням клітинної ланки імунітету за зниженням ЛІ виявляли у обстежених дітей від 16,7 до 32\% в групах після різних видів радикального лікування, але частіше у $32 \%$ дітей цей показник був знижений після комбінованого лікування $\mathrm{O}+\mathrm{XT}$.

У середньому 46,7\% дітей, що надійшли на СКЛ після всіх видів радикального лікування $3 \mathrm{H}$, мали порушення співвідношення активності клітин неспецифічного та специфічного імунного захисту з пригніченням специфічного компоненту за данними збільшення коефіцієнту ICНЛ.

У середньому у 44\% обстежених дітей після лікування 3Н виявлявся підвищений індекс алергізації (IA). Більш відхилений IA до $(1,8 \pm 0,3)$ ум. одиниць виявляли після комбінованого радикального лікування з хіміотерапією.

Посилення пригнічення ефекторних імунокомпетентних клітин, активності макрофрагальномікрофрагальної системи визначені частіше після комбінованого лікування О + ХТ + П та О + ХT.

Посилення порушень співвідношення активності клітинної та гуморальної ланок з пригніченням клітинної ланки імунітету, підвищення IA визначені частіше після комбінованого лікування О + XT.

Таким чином, порушення імунологічної реактивності у дітей, які надходили на СКЛ після радикального лікування $3 \mathrm{H}$, частіше проявлялись порушеннями активності клітин неспецифічного та специфічного імунного захисту з пригніченням специфічного компоненту и не залежали від видів радикального лікування.

\section{Висновки}

1. У дітей, пролікованих з приводу ЗН, при надходженні на СКЛ з більшою частотою виявляються 
порушення всіх ланок імунітету, ніж у дітей у ремісії ОГЗ. Особливо це стосується дітей із ЗН після комбінованого лікування О + ХT.

2. У дітей в стані ремісії ОГЗ після ХТ частіше пригнічується активність клітинної ланки імунітету та підвищується індекс лейкоцитарної інтоксикації.

3. У дітей в стані ремісії ОГЗ після ХТ + ПТ частіше пригнічується активність макрофагальної системи, як ефекторної ланки імунітету.
Перспективи подальших досліджень. Слід вважати доцільною оцінку стану імунітету дітей у ремісії онкологічних захворювань після базисного антиканцерогенного лікування після проведення різних курсів санаторно-курортної реабілітації з метою додаткового обгрунтування їх необхідності.

\section{References}

1. Lazorishinets VV, Moiseenko RO, Poberskaya VO, et al. Basic principles of organization and methodology of rehabilitation of children with oncological and oncohematological diseases in Ukraine. Medical rehabilitation, health resort, physiotherapy. 2010; 2: 3-7. [Ukrainian].

2. Kaladze NN. Features of rehabilitation of the children with oncolohematological pathology. Herald for Physiotherapy and Balneology. 2011; 4: 47-57 [Russian].

3. Goryachkovsky AM. Clinical biochemistry in laboratory diagnostics: reference manual. 2nd ed. Odessa: Ecology, 2005. - 616 p. [Ukrainian].

4. Speransky VV, Dmitrieva II, Zaripova RM. Immunological informativeness of leukocytogram. Klin lab diagnostics. 1999; 12: 6-7. [Ukrainian].

5. Poberska VO, Yanchenko TS, Yevsyeyeva SV, ta in. Porivnyalna otsinka vidnovlyuvalnogo likuvannya ditey z onkologichnimi zakhvoryuvannyami na ambulatornomu ta sanatorno-kurortnomu etapakh reabilitatsiyi. Medichna reabilitatsiya, kurortologiya, fizioterapiya. 2010; 1: 3-7. [Ukrainian].

\section{УДК 616-006-036.66-053.4-071:4-071:616-036.82:615.838 \\ ХАРАКТЕРИСТИКА СОСТОЯНИЯ ИММУНИТЕТА ДЕТЕЙ В РЕМИССИИ ОНКОЛОГИЧЕСКИХ ЗАБОЛЕВАНИЙ ПОСЛЕ БАЗИСНОГО АНТИКАНЦЕРОГЕННОГО ЛЕЧЕНИЯ}

\section{Шаповалова А. А., Бабова И. К., Бабов К. Д.}

Резюме. В результате оценки состояния иммунитета детей в ремиссии онкологических заболеваний после базисного антиканцерогенного лечения установлено следующее.

Дети в ремиссии ОГЗ, которые поступали на СКЛ, имели нарушение по данным расчетных интегративных показателей иммунологической реактивности. Чаще это выявлялось после получения комбинированной XT + ЛТ. Нарушение соотношения активности клеточного и гуморального звеньев с угнетением клеточного звена иммунитета (снижение ЛИ) регистрировалось приблизительно с одинаковой частотой после различных протоколов базисного лечения. Нарушение иммунологической реактивности у детей, которые поступали на СКЛ после радикального лечения $3 \mathrm{H}$, чаще проявлялись нарушениями активности клеток неспецифической и специфической иммунной защиты с угнетением специфического компонента и не зависели от видов радикального лечения. Таким образом, у детей, пролеченных по поводу 3Н, при поступлении на СКЛ с большей частотой выявляются нарушения всех звеньев иммунитета, чем у детей в ремиссии ОГЗ.

Ключевые слова: дети, онкологические заболевания, антиканцерогенное лечение, состояние иммунитета.

\section{UDC 616-006-036.66-053.4-071:4-071:616-036.82:615.838}

Characteristics of the Children Immunity State in the period

of Oncological Remission after Basic Anticarcinogenic Treatment

Shapovalova G. A., Babova I. K., Babov K. D.

Abstract. Over the past 10 years, the rate of childhood disability in Ukraine has increased 2 times due to malignant neoplasms (MN) of lymphatic and hematopoietic tissue. In the structure of the overall incidence of children, the cancer increase is observed by $20 \%$. Moreover, the prevalence of cancer among adolescents increased by $26 \%$ during the last 5 years.

The purpose of the study is to evaluate the children immune state in the period of cancer remission after basic anticarcinogenic treatment.

Materials and methods. To evaluate the immunological reactivity of the organism, we determined the integral hematological parameters: LI (lymphocytic index); RLESR - the ratio of leukocytes and erythrocyte 
sedimentation rate (ESR); INLR - index of neutrophils and lymphocytes ratio; INMR - index of neutrophils and monocytes ratio; ISLM - index of lymphocytes and monocytes ratio; IA - index of allergy; LII - leukocyte index of intoxication.

Results and discussion. The immunity state was evaluated in 152 children in the period of remission of oncohematological diseases (OHD) and MN after basic treatment (operative treatment (OT), chemotherapy (CT), radiotherapy $(\mathrm{RT})$ upon admission to hospital treatment.

There appeared the afferent and efferent immunity ratio violation in children in the period of OHD remission after receiving combined treatment courses when admitted to hospital.

This indicator was increased in $19.6 \%$ of children after basic treatment with CT after combined therapy with $\mathrm{HT}+\mathrm{PT}$ in $35.1 \%$ of the subjects. Chronic moderate changes in the macrophage-microphage system are also determined by the increase of ISMM. The ISMM increased in $54 \%$ of children to $(17.3 \pm 2.6)$ units after CT + RT. In children undergoing $\mathrm{OHD}$ remission after $\mathrm{CT}$, these shifts were determined with less deviations $(13.5 \pm 2.2)$ units with a lower frequency of $35.3 \%$. Violation of the ratio of activity of the cellular and humoral units with inhibition of the cellular level of immunity (a decrease in the level of lymphocytes of the Harkavy Index, LI) was found in $25.5 \%$ of children after CT and in $16.2 \%$ of children after receiving CT + RT, with a rise in the neutrophilic ratio index and lymphocytes (NRIL) in these groups of children, indicating a decrease in cells of specific body protection. Increased index of allergy in children after CT and combined CT + RT was found, but more pronounced in the first case. However, with CT more often (in $25.5 \%$ of patients), when entering to hospital treatment, the leukocyte index of intoxication (LII) was reduced, indicating the viral load of the organism.

One third of the children on admission to hospital after MN treatment had the oppression to production of effector immunocompetent monocytes cells according to the increase of ISL. The greater deviations of this index in the average in $38 \%$ of the surveyed were determined after the protocols OT + CT, OT + CT + RT, the smallest deviations and were less common in $21.6 \%$ of those examined after OT. Chronic moderate changes in the macrophage-microphage system were determined at an average frequency $(45.6 \%)$ after all types of radical treatment, but higher rates of ICNM were determined in cases after the combination of radical treatment $\mathrm{OT}+\mathrm{CT}+\mathrm{RT}$ and OT + CT. On average, $46.7 \%$ of children who were treated in hospital after all types of radical $\mathrm{MN}$ treatment had a violation of the ratio of cells activity of nonspecific and specific immune defense with inhibition of a specific component, with the increase of the INMR coefficient.

Conclusions. Children in OHD remission had violations according to the calculated integrative indicators of immunological reactivity. This is most often manifested after receiving a combined CT + RT. Violation of the ratio of activity of the cellular and humoral units with inhibition of the cellular level of immunity (decrease in LI) was found to be approximately the same frequency after various protocols of basic treatment. Violations of immunological reactivity in children who were treated in hospital after radical MN treatment were more often manifested by violations of the activity of cells of nonspecific and specific immune defense with oppression to a specific component and did not depend on the types of radical treatment.

Keywords: children, oncological diseases, anti-carcinogenic treatment, state of immunity.

Стаття надійшла 24.11.2017 p. Рекомендована до друку на засіданні редакційної колеаії після рецензування 